\title{
Impact of Mulching on Wheat Yield and Weed Floras in the Mid-hills of Nepal
}

\author{
Jagat D. Ranjit ${ }^{1}$, Robin Bellinder ${ }^{2}$, Julie Lauren ${ }^{3}$ and John M. Doxhbury ${ }^{3}$ \\ ${ }^{1}$ Agronomy Division, NARC, Khumaltar, Lalitpur, Nepal < nepaljdr@yahoo.com> \\ ${ }^{2}$ Department of Horticulture, Cornell University, USA \\ ${ }^{3}$ Department of Crop and Soil science, Cornell University, USA
}

\begin{abstract}
Studies on the effect of mulching and weed management strategies in wheat were initiated at Khumaltar during the winter season of 2000-2002. The treatments were weedy check, handweed alone, post emergence application of sulfosufuron, and NPK application together with or without mulching. Rice straw mulch was applied at the rate of $4 \mathrm{t} / \mathrm{ha}$. Phalaris minor, Alopecuros sp., Chenopodium album, Rumex crispus, Polygonum hydropiper, Stellaria media, Cannabis sativa, and Soliva anthemifolia were the dominant species. Among them, C. album, P. minor and Alopecuros aqualis were the dominant species. The effect of mulching was seen six weeks after wheat planting. The weedy check with mulch suppressed the weeds about fifty percent compared to that of without mulching. Wheat yields together with yield attributing characters were also higher in the treatments with straw mulch.
\end{abstract}

Key words: Management, mulching, suppression, weed floras, wheat

\section{INTRODUCTION}

Rice and wheat are the basic staple foods for the Indogangetic region of South Asia. The rice-wheat rotation is the main cropping system in this region. This is also a dominant production system in Nepal. The wheat crop occupies about 0.66 million hectares with an average productivity of 2.07 t $/$ ha. Weeds play an important role in the production system. Many grass and broadleaf weeds are associated with wheat crop. Among them, Phalaris minor, a graminicious weed, is spreading and posing a serious problem in the cultivation of wheat in many parts of different agro-ecological regions of Nepal (Ranjit et al 2006). This weed mimics the wheat plants and sets seeds at almost the same time and height as the crop. Now this weed has developed resistance to isoproturon herbicide in neighboring countries. However, isoproturon resistant $P$. minor has not been recorded yet in Nepal. But researchers, extension agents and wheat growers must be careful to keep from spreading this weed in the future. Depending upon location, this weed is known by different names such as Ragate, Gahun ko mama, Ledai, Thulo matte, and Tago naincha (Ranjit et al 2006). Weeds can reduce wheat yield up to 50 percent sometimes even higher depending upon the population density and species. 
Research has been carried out in many countries, including South Asia to minimize infestations of $P$. minor. A number of studies showed that mulching as well as herbicides could minimize both grass and broadleaf weeds in wheat. Among straw mulches tested, rice straw at the rate of $10 \mathrm{t} / \mathrm{ha}$ gave significantly higher yield of wheat than when no mulch was used (Upadhyaya and Tiwari 1996). Rice and sugarcane straw mulches were tested in wheat. Variable effects were observed over the years. Both types of mulches performed well giving 100 percent weed suppression. Grain yields were the lowest without mulch (Ullah et al 1998). Wheat yield and nutrient uptake were different with straw management. Among the different straw management, e.g. soil incorporation of chopped straw, soil incorporation of well rotten animal manure, and soil incorporation of animal manure together with chopped straw at $5 \mathrm{t} / \mathrm{ha}$, the wheat yield and nutrient uptake were the highest under paddy straw incorporation with animal manure and animal manure incorporation (Verma and Bhagat 1994).

Paddy straw mulch was more effective in suppressing weeds in wheat than was stubble of the preceding crop or white polyethylene (500 gauges) lay between the rows. Nitrogen at $25 \mathrm{~kg} / \mathrm{ha}$ and $50 \mathrm{~kg} / \mathrm{ha}$ had no significant effect on weed populations under rainfed conditions. Maximum root growth and water uptake were obtained at $120 \mathrm{~kg} / \mathrm{ha} \mathrm{N}$ and in mulched treatments. The leaf area index was higher in conventional tillage and minimum tillage plus Lantana camera mulch (Verma and Acharya 1996). Wheat yields were similar in conventional and no tillage when rice mulch was spread after seeding in the northern Thailand (Jongdee et al 1994). Rice straw mulch plus sulfosulfuron@26 gm ai/ha and sulfosulfuron@28 gm ai/ha plus hand weeding one were the best in terms of weed suppression and yield attributes of wheat (Ranjit and Suwanketnikom 2003). Rice straw mulch increased wheat yield and suppressed weeds (Roy 1989, Ning and Hu 1990). Paddy straw mulch was more effective than the stubble of the preceding crop under rainfed wheat.

The objective of this study was to evaluate the effect of different weed management strategies with and without rice straw mulch on weeds in wheat in mid hill region of Nepal.

\section{MATERIALS AND METHODS}

The mulching experiment was initiated to evaluate its effect on wheat yields, yield parameters and weed floras at Khumaltar in two successive winter seasons during 2000/2001 and 2001/2002. The cropping system of the experimental plot was rice-wheat. The experiment was laid out in randomized complete block design with plot size of $2-\times 5-\mathrm{m}$ and the row spacing $25 \mathrm{~cm}$. The variety used was Annapurna-4. The seed rate was $120 \mathrm{~kg} / \mathrm{ha}$. Chemical fertilizer was applied at the rate of 80:40:20 N: $\mathrm{P}_{2} \mathrm{O}_{5}: \mathrm{K}_{2} \mathrm{O} \mathrm{kg} / \mathrm{ha}$. Nitrogen was given in two split doses of basal and topdressing into two equal halves. The treatment combinations were no weeding, one hand weeding, post emergence application of sulfosulfuron @ 28 gm /ha and placement of $\mathrm{N}: \mathrm{P}_{2} \mathrm{O}_{5}: \mathrm{K}_{2} \mathrm{O}$ (basal dose of NPK applied 10 days after wheat emergence) with and without straw mulch. Sulfosulfuron was mixed with surfactant before application. Chopped rice straw mulch was applied at the rate of $4 \mathrm{t} / \mathrm{ha}$ one day after wheat planting. Flood irrigation was given fifty days after wheat sowing.

The number of weeds was recorded from $0.50 \mathrm{~m}^{2}$ quadrats at 5 and 12 weeks after wheat seeding. Fresh and dry weed biomass was recorded from $0.50 \mathrm{~m}^{2}$ after cutting the root parts. Post emergence herbicide was applied 8 weeks after wheat seeding when the grass weeds had 4-6 leaves. Herbicide was applied with a 4-nozzle power operated backpack sprayer. Flat fan nozzles were used. Wheat planting was done on 24 Nov 2000 and 23 Nov 2001 in 2000 and 2001 respectively. Harvesting was done in 24 May 2001 and 28 May 2002 in 2000 and 2001 respectively. Data were analyzed by using MSTATC statistical package (Anonymous 1986). 


\section{RESULTS AND DISCUSSION}

\section{EFFECT ON WEEDS}

Weeds like Chenopodium album, Rumex sp., Polygonum hydropiper, Stellaria media, Cannabis sativa, Senecio vulgaris were among the broadleaf weeds and Phalaris minor and Alopecuros sp. were among the grass weeds in the experimental field. Among them, C. album, P. minor and Alopecuros were the dominant weeds. In both the years, the number of broadleaf was higher than the grass weeds.

Both grass and broadleaf weeds were suppressed by the straw mulch. Sulfosulfuron herbicide reduced both groups of weeds. Sulfosulforon with mulch reduced grasses by 40 percent compared to no mulch. Placement of NPK reduced weed populations both with mulch and without mulch compared to other treatments 5 weeks after seeding. However, weed populations increased by 12 weeks after seeding, but weed numbers were less with mulch. Broadleaf weeds were comparatively higher than grasses in the NPK placement treatment during 2000/2001 (Table 1 and 2).

Table 1. Effect of different treatments on weeds at five weeks after seeding (WAS) in wheat at Khumaltar, 2000/01 to 2001/02

\begin{tabular}{|c|c|c|c|c|c|c|c|c|c|c|c|c|}
\hline \multirow{4}{*}{ Treatments } & \multirow{2}{*}{\multicolumn{6}{|c|}{ Broadleaf }} & \multicolumn{6}{|c|}{ Weed count at $5 \mathrm{WAS} / 0.50 \mathrm{~m}^{2}$} \\
\hline & & & & & & & & & $\mathrm{Gr}$ & & & \\
\hline & \multicolumn{2}{|c|}{$2000 / 01$} & \multicolumn{2}{|c|}{ 2001/02 } & \multicolumn{2}{|c|}{ Mean } & \multicolumn{2}{|c|}{$2000 / 01$} & \multicolumn{2}{|c|}{ 2001/02 } & \multicolumn{2}{|c|}{ Mean } \\
\hline & $\begin{array}{c}\text { No } \\
\text { mulch }\end{array}$ & Mulch & $\begin{array}{l}\text { No } \\
\text { mulch }\end{array}$ & Mulch & $\begin{array}{l}\text { No } \\
\text { mulch }\end{array}$ & Mulch & $\begin{array}{l}\text { No } \\
\text { mulch }\end{array}$ & Mulch & $\begin{array}{c}\text { No } \\
\text { mulch }\end{array}$ & Mulch & $\begin{array}{l}\text { No } \\
\text { nulch }\end{array}$ & Mulch \\
\hline Check & 125 & 78 & 258 & 354 & 192 & 216 & 106 & 46.6 & 24 & 7 & 65 & 27 \\
\hline Hand weeding $\dagger$ & 140 & 90 & 265 & 476 & 203 & 283 & 99 & 47 & 20 & 8 & 60 & 28 \\
\hline Sulfosulfuron $\uparrow \dagger$ & 118 & 88 & 447 & 552 & 283 & 320 & 93 & 50 & 28 & 16 & 61 & 33 \\
\hline NPK placement & 82 & 59 & 371 & 407 & 277 & 233 & 51 & 28 & 31 & 12 & 41 & 20 \\
\hline F-test & & $* *$ & & ns & & & & $*$ & & ns & & \\
\hline $\operatorname{LSD}(0.05)$ & & 24 & & - & & & & 44 & & - & & \\
\hline
\end{tabular}

†One handweeding; ††@ 28 g/ha.ns, not significant; *, significant; **, highly significant.

Table 2. Effect of different treatments on weeds at 12 weeks after seeding (WAS) in wheat at Khumaltar, 2000/01 to 2001/02

\begin{tabular}{|c|c|c|c|c|c|c|c|c|c|c|c|c|}
\hline \multirow{4}{*}{ Treatments } & & & & & & & \multicolumn{6}{|c|}{ Weed count at $12 \mathrm{WAS} / 0.50 \mathrm{~m}^{2}$} \\
\hline & \multicolumn{6}{|c|}{ Broadleaf } & \multicolumn{6}{|c|}{ Grass } \\
\hline & \multicolumn{2}{|c|}{$2000 / 01$} & \multicolumn{2}{|c|}{200102} & \multicolumn{2}{|c|}{ Mean } & \multicolumn{2}{|c|}{$2000 / 01$} & \multicolumn{2}{|c|}{ 2001/02 } & \multicolumn{2}{|c|}{ Mean } \\
\hline & $\begin{array}{l}\text { No } \\
\text { mulch }\end{array}$ & Mulch & $\begin{array}{l}\text { No } \\
\text { mulch }\end{array}$ & Mulch & $\begin{array}{l}\text { No } \\
\text { mulch }\end{array}$ & Mulch & $\begin{array}{l}\text { No } \\
\text { mulch }\end{array}$ & Mulch & $\begin{array}{l}\text { No } \\
\text { mulch }\end{array}$ & Mulch & $\begin{array}{l}\text { No } \\
\text { mulch }\end{array}$ & Mulch \\
\hline Check & 166 & 98 & 1034 & 478 & 600 & 288 & 86 & 67 & 26 & 26 & 56 & 47 \\
\hline Hand weeding & 35 & 37 & 161 & 177 & 98 & 107 & 19 & 21 & 24 & 28 & 22 & 25 \\
\hline $\begin{array}{l}\text { Sulfosulfuron } \\
\text { @ } 28 \mathrm{~g} / \mathrm{ha}\end{array}$ & 54 & 44 & 274 & 224 & 164 & 134 & 11 & 17 & 11 & 16 & 11 & 17 \\
\hline $\begin{array}{l}\text { NPK } \\
\text { placement }\end{array}$ & 126 & 104 & 258 & 377 & 192 & 241 & 70 & 57 & 54 & 39 & 62 & 48 \\
\hline F-test & & $* *$ & & $* *$ & & & & $* *$ & & ns & & \\
\hline LSD $(0.05)$ & & 29 & & 223 & & & & 21 & & - & & \\
\hline
\end{tabular}

†One handweeding; ††@ 28 g/ha. ns, not significant; *, significant; **, highly significant.

There was no significant difference in weed numbers during the first four weeks after wheat seeding. Grass weeds were less compared to broadleaf weeds both in mulch and no mulch treatments. Weed populations differed in mulch and no mulch treatments 60 days after seeding. There were significant differences between the number of broadleaf and grass weeds. However, there was not much impact of sulfosulfuron and NPK placement on broadleaf weeds in either mulch or no mulch treatments. In the weedy check, mulch suppressed on broadleaf weeds in 2001/02 (Table 1 and 2).

The two year mean data showed that grass weeds were affected by the mulch both 5 and 12 weeks after wheat seeding. There were no differences in weed suppression with handweeding alone and NPK placement did regardless of mulching. The weedy check and sulfosulfuron, with and without mulch suppressed both groups of weeds (Table 1 and 2)). 
Both broadleaf and grass weed biomass were less in mulch treatments. NPK placement without mulch and the weedy check without mulch gave comparable weed biomass as compared to handweeding and sulfosulfuron application. Weed biomass was similar in the weedy check, NPK placement. Grass weed weight was also less in mulch compared to without mulch (Table 3).

Table 3. Effect of treatments on weed biomass in wheat at Khumaltar

\begin{tabular}{|c|c|c|c|c|c|c|c|c|c|c|c|c|}
\hline \multirow{4}{*}{ Treatments } & & & & & & & \multicolumn{6}{|c|}{ Weed Biomass at $12 \mathrm{WAS} / 0.50 \mathrm{~m}^{2}$} \\
\hline & \multicolumn{6}{|c|}{ Broadleaf } & \multicolumn{6}{|c|}{ Grass } \\
\hline & \multicolumn{2}{|c|}{$2000 / 2001$} & \multicolumn{2}{|c|}{$2001 / 02$} & \multicolumn{2}{|c|}{ Mean } & \multicolumn{2}{|c|}{$2000 / 2001$} & \multicolumn{2}{|c|}{$2001 / 02$} & \multicolumn{2}{|c|}{ Mean } \\
\hline & $\begin{array}{l}\text { No } \\
\text { mulch }\end{array}$ & Mulch & $\begin{array}{c}\text { No } \\
\text { mulch }\end{array}$ & Mulch & $\begin{array}{l}\text { No } \\
\text { mulch }\end{array}$ & Mulch & $\begin{array}{c}\text { No } \\
\text { mulch }\end{array}$ & Mulch & $\begin{array}{l}\text { No } \\
\text { mulch }\end{array}$ & Mulch & $\begin{array}{c}\text { No } \\
\text { mulch }\end{array}$ & Mulch \\
\hline Check & 43.3 & 31.6 & 18.1 & 7.1 & 31 & 19 & 13.0 & 16.5 & 0.96 & 0.86 & 7 & 7 \\
\hline Handweeding $\dagger$ & 5.8 & 10.0 & 3.2 & 2.4 & 5 & 6 & 2.8 & 4.0 & 0.61 & 0.79 & 2 & 2 \\
\hline Sulfosulfuron $\uparrow \dagger$ & 13.3 & 12.0 & 3.9 & 1.6 & 9 & 7 & 3.8 & 5.3 & 0.30 & 0.27 & 2 & 3 \\
\hline NPK placement & 38.3 & 30.2 & 14.7 & 7.6 & 27 & 19 & 5.8 & 7.0 & 2.10 & 1.50 & 4 & 4 \\
\hline F-test & & $* *$ & & $* *$ & & & & ns & & $*$ & & \\
\hline $\operatorname{LSD}(0.05)$ & & 10 & & 3 & & & & - & & 0.55 & & \\
\hline
\end{tabular}

†One handweeding; ††@ 28 g/ha.ns, not significant; *, significant; **, highly significant.

\section{EFFECT ON YIELD PARAMETERS}

The effect of mulching was noted in wheat plants in 6 weeks after wheat seeding. Wheat plants were dark green in all the treatments with mulch compared to without mulch. There was a significant difference in the number of tillers $/ \mathrm{m}^{2}$ and grain yield in 2000/2001. Tillers $/ \mathrm{m}^{2}$ ranged from 202 in the weedy check without mulch to 399 in sulfosulfuron plus mulch. Tillers $/ \mathrm{m}^{2}$ was more in mulch compared to no mulch in all treatments except the NPK placement. Grain yield was significantly different, yielding higher in treatments with straw mulch. The highest grain yields were 4104 and $3878 \mathrm{~kg} / \mathrm{ha}$ recorded in sulfosulfuron with and without mulch, respectively, followed by hand weeding (3770 and $3478 \mathrm{~kg} / \mathrm{ha}$ ) with and without mulch. The lowest grain yield 2819 and 1684 $\mathrm{kg} / \mathrm{ha}$, was recorded in the weedy check with and without mulch respectively. In all treatments, grain yields were higher with mulch compared to without mulch (Table 4).

Table 4. Treatment effect on the yield attributes of wheat at Khumaltar, 2000/2001 to 2001/02

\begin{tabular}{|c|c|c|c|c|c|c|c|c|c|c|c|c|}
\hline \multirow{3}{*}{ Treatments } & \multicolumn{6}{|c|}{ Plant height, $\mathrm{cm}$} & \multicolumn{6}{|c|}{ Tillers $/ \mathrm{m}^{2}$} \\
\hline & \multicolumn{2}{|c|}{$2000 / 01$} & \multicolumn{2}{|c|}{$2001 / 02$} & \multicolumn{2}{|c|}{ Mean } & \multicolumn{2}{|c|}{$2000 / 01$} & \multicolumn{2}{|c|}{$2001 / 02$} & \multicolumn{2}{|c|}{ Mean } \\
\hline & $\begin{array}{l}\text { No } \\
\text { mulch }\end{array}$ & Mulch & $\begin{array}{l}\text { No } \\
\text { mulch }\end{array}$ & Mulch & $\begin{array}{l}\text { No } \\
\text { mulch }\end{array}$ & Mulch & $\begin{array}{l}\text { No } \\
\text { mulch }\end{array}$ & Mulch & $\begin{array}{l}\text { No } \\
\text { mulch }\end{array}$ & Mulch & $\begin{array}{l}\text { No } \\
\text { mulch }\end{array}$ & Mulch \\
\hline Check & 111 & 111 & 95 & 108 & 111 & 110 & 202 & 242 & 125 & 273 & 164 & 258 \\
\hline $\begin{array}{l}\text { Hand weeding } \\
\text { one }\end{array}$ & 113 & 113 & 105 & 108 & 113 & 111 & 285 & 300 & 184 & 262 & 235 & 281 \\
\hline $\begin{array}{l}\text { Sulfosulfuron @ } \\
28 \text { g/ha }\end{array}$ & 114 & 114 & 101 & 105 & 114 & 110 & 372 & 399 & 207 & 222 & 290 & 311 \\
\hline NPK placement & 113 & 115 & 92 & 101 & 113 & 108 & 277 & 270 & 119 & 199 & 198 & 235 \\
\hline F-test & & ns & & $*$ & & & & $* *$ & & $* *$ & & \\
\hline $\operatorname{LSD}(0.05)$ & & - & & 5.2 & & & & 39 & & 23.3 & & \\
\hline
\end{tabular}

Table 4. Contd...

\begin{tabular}{|c|c|c|c|c|c|c|c|c|c|c|c|c|}
\hline \multirow{3}{*}{ Treatments } & \multicolumn{6}{|c|}{ Seeds/panicle } & \multicolumn{6}{|c|}{1000 seed wt, $g$} \\
\hline & \multicolumn{2}{|c|}{$2000 / 01$} & \multicolumn{2}{|c|}{$2000 / 01$} & \multicolumn{2}{|c|}{$2000 / 01$} & \multicolumn{2}{|c|}{$2000 / 01$} & \multicolumn{2}{|c|}{$2000 / 01$} & \multicolumn{2}{|c|}{$2000 / 01$} \\
\hline & $\begin{array}{c}\text { No } \\
\text { mulch }\end{array}$ & Mulch & $\begin{array}{c}\text { No } \\
\text { mulch }\end{array}$ & Mulch & $\begin{array}{c}\text { No } \\
\text { mulch }\end{array}$ & Mulch & $\begin{array}{l}\text { No } \\
\text { mulch }\end{array}$ & Mulch & $\begin{array}{c}\text { No } \\
\text { Mulch }\end{array}$ & Mulch & $\begin{array}{c}\text { No } \\
\text { mulch }\end{array}$ & Mulch \\
\hline Check & 43 & 52 & 43 & 52 & 43 & 52 & 33 & 32 & 37 & 36 & 35 & 34 \\
\hline $\begin{array}{l}\text { Hand weeding } \\
\text { one }\end{array}$ & 54 & 49 & 50 & 48 & 52 & 49 & 32 & 31 & 35 & 35 & 34 & 33 \\
\hline $\begin{array}{l}\text { Sulfosulfuron@ } \\
28 \text { g/ha }\end{array}$ & 53 & 47 & 43 & 45 & 48 & 46 & 32 & 32 & 37 & 37 & 35 & 35 \\
\hline NPK placement & 58 & 47 & 45 & 46 & 52 & 47 & 33 & 31 & 35 & 35 & 34 & 33 \\
\hline F-test & & ns & & ns & & ns & & ns & & ns & & ns \\
\hline LSD $(0.05)$ & & - & & - & & - & & - & & - & & - \\
\hline
\end{tabular}




\begin{tabular}{|c|c|c|c|c|c|c|}
\hline \multirow{3}{*}{ Treatments } & \multicolumn{6}{|c|}{ Yield, kg/ha } \\
\hline & \multicolumn{2}{|c|}{$2000 / 01$} & \multicolumn{2}{|c|}{$2001 / 02$} & \multicolumn{2}{|c|}{ Mean } \\
\hline & No mulch & Mulch & $\begin{array}{c}\text { No } \\
\text { Mulch }\end{array}$ & Mulch & $\begin{array}{c}\text { No } \\
\text { mulch }\end{array}$ & Mulch \\
\hline Check & 1684 & 2819 & 1569 & 2715 & 1627 & 2767 \\
\hline Hand weeding one & 3478 & 3770 & 2439 & 3028 & 2959 & 3399 \\
\hline Sulfosulfuron@28 g/ha & 3878 & 4104 & 2693 & 3084 & 3286 & 3594 \\
\hline NPK placement & 1886 & 3018 & 1645 & 2003 & 1766 & 2511 \\
\hline F-test & & $* *$ & & $*$ & & \\
\hline $\operatorname{LSD}(0.05)$ & & 344 & & 456 & & \\
\hline
\end{tabular}

Plant height, tillers $/ \mathrm{m}^{2}$ and grain yield were significantly different in $2001 / 02$. Plant height ranged from $92 \mathrm{~cm}$ in NPK placement plus no mulch to $107 \mathrm{~cm}$ in sulfosulfuron, handweeding plus mulch. Number of tillers $/ \mathrm{m}^{2}$ ranged from tillers $/ \mathrm{m}^{2} 119 / \mathrm{m}^{2}$ in NPK placement plus no mulch to $\left(273 / \mathrm{m}^{2}\right)$ in mulch plus weedy check. Grain yield was lower in 2001/02 than in 2000/01. However, grain yields were higher in all treatments with mulch (Table 4). The two year mean showed that there is not much differences in plant height, seeds per panicle and thousand seed weight. But tillers per square meter and grain yield were higher in all treatments with mulch than without mulch (Table 4).

\section{CONCLUSION}

Phalaris minor and Alopecuros sp. were major grass weeds in the wheat field. Chenopodium album, Rumex sp., Stellaria media, Polygonum hydropiper and Senecio vulgaris were among the broadleaf weeds. Straw mulch reduced broadleaf as well as grass weeds in both the years. About 50 percent weeds were reduced in no weeding with mulch. The suppression of grass weeds by sulfosulfuron plus mulch was higher. Mulch increased grain yield of wheat. Higher yield was recorded with herbicide plus mulch in both the years. From this study, it can be concluded that rice straw mulch alone may achieve significantly higher yields than control. However, it is possible to increase grain yield by adding herbicide or hand weeding to mulch in the mid hill regions.

\section{ACKNOWLEDGMENTS}

The authors are grateful to Nepal Agriculture Research Council (NARC)/Nepal and Cornell/USA for approving and funding this study, respectively. We are thankful to all the staff of Agronomy Division, Khumaltar for their direct and indirect help throughout the study period.

\section{REFERENCES}

Anonymous. 1986. MSTATC User's guide. East Lansing, Michigan State University, USA.

Jongdee B, DA Saunders and GP Hettel. 1994. Tillage methods for wheat after rice in paddy soils in Thailand. Wheat in heat stressed environments: irrigated, dry areas and rice-wheat farming systems. In: Proceedings of the international conferences held at Wad Medani, Sudan 1-4 February 1993 and Dinapur, Bangladesh 13-15 Feb., 1993. Pp. 272-275. 
Ning CG and TG Hu. 1990. The role of straw covering in crop production and soil management. Better Crops International 6(2):6-7.

Ranjit JD and R Suwanketnikom. 2003. Response of weeds and wheat yield to tillage and weed management. Kasetsart J. Nat. Sci. 37:389-400.

Ranjit JD, RR Bellinder, P Hobbs, NK Rajbhandari and P Kataki. 2006. Mapping Phalaris minor under the rice-wheat cropping system in different agro-ecological regions of Nepal. Nepal Ag. Research Journal 7:54-62.

Roy K. 1989. Effects of mulching and nitrogen application on weed population in rainfed wheat. Agricultural Science Digest 9(2):102-104.

Upadhyaya VB and JP Tiwari. 1996. Influence of nitrogen, seed rate and mulch on wheat (Triticum aestivum) varieties under late sowed conditions. Indian Journal of Agronomy 41:4,562-565.

Ullah R, A Rashid, A Khan and S Gulam. 1998. Effect of different mulching materials on the growth and production of wheat crop. Sarhad Journal of Agriculture 14:1,21-25.

Verma TS and RM Bhagat. 1994. Nutrient dynamics and wheat yield as influenced by paddy straw management practices. Crop Research, Hissar 7(3):382-390.

Verma MC and CL Acharya. 1996. Root development, leaf area index, water use and yield of rainfed wheat under different soil conservation practices and levels of nitrogen. Journal of the Indian Society of Soil Science 44(4):625-632. 